\title{
PENGARUH CITRA MEREK DAN KOMITMEN TERHADAP PEMBELIAN KEMBALI LIPSTIK MEREK WARDAH DI KOTA PALU
}

\author{
Ni Luh Ayu Ghitaswari \\ Elimawaty Rombe \\ Ponirin \\ Jurusan Manajemen, Fakultas Ekonomi, Universitas Tadulako \\ Email: ayu.ghitaswari@yahoo.co.id
}

\begin{abstract}
This study aims to identify and analyze: (1) the influence of brand image and commitment on repurchasing Wardah lipstick in Palu City, (2) the influence of brand image on repurchasing Wardah lipstick in Palu City,(3) the influence of commitment on repurchasing Wardah lipstick in Palu City. The type of research is causality to show the relationship between variables. The population of this research consists of all consumers who have used Wardah lipstick in Palu City. Sampling method used is purposive sampling, with total sample of 100 respondents. Retrieving data using online questionnaires have tested for validity and reliability. The analytical method using analysis regression. The results show that (1) brand image and commitment simultaneously have significant influence on repurchasing Wardah lipstick in Palu City, (2) brand image partially has significant influence on repurchasing Wardah lipstick in Palu City, (3) commitment partially has significant influence on repurchasing Wardah lipstick in Palu City.
\end{abstract}

Keywords: Brand image, Commiment, repurchasing.

\section{ABSTRAK}

Penelitian ini bertujuan untuk mengetahui dan menganalisa: (1) Pengaruh Citra merek dan Komitmen terhadap pembelian kembali lipstik merek Wardah di Kota Palu, (2) Pengaruh Citra merek terhadap pembelian kembali lipstik merek Wardah di Kota Palu, (3) Pengaruh komitmen terhadap pembelian kembali lipstik merek Wardah di Kota Palu. Jenis penelitian yang digunakan adalah kausalitas (menunjukan hubungan antarvariabel). Populasi penelitian ini adalah seluruh para konsumen yang telah menggunakan produk Lipstik merek Wardah di Kota Palu. Teknik penarikan sampel dalam penelitian ini menggunakan purposive sampling, dengan jumlah sampel sebanyak 100 responden. Pengambilan data menggunakan kuesioner online yang telah diuji validitas dan reliabilitasnya. Metode analisis menggunakan analisis regresi berganda. Hasil penelitian menunjukkan bahwa (1) Citra merek dan komitmen secara simultan berpengaruh signifikan terhadap pembelian kembali lipstik merek Wardah di Kota Palu, (2) Citra merek secara parsial berpengaruh signifikan terhadap pembelian kembali lipstik merek Wardah di Kota Palu, (3) Komitmen secara parsial berpengaruh signifikan terhadap pembelian kembali lipstik merek Wardah di Kota Palu.

Kata Kunci: Citra merek, Komitmen, Pembelian kembali

\section{PENDAHULUAN}

Seiring meningkatnya jumlah perempuan yang memperhatikan penampilan, maka industri kosmetik akan terus berkembang. Selain dipenuhi pemain industri kosmetik lokal, perusahan kosmetik asing pun turut memasuki pasar Indonesia yang potensial (sumber: www.marketers.com.2015). Selain itu, adanya pasar bebas di negara ASEAN seperti Masyarakat Ekonomi Asean (MEA) membuat persaingan industri kosmetik semakin bertambah. Lipstick Wardah merupakan merek lokal yang saat ini tengah naik daun. Apalagi Wardah sudah mengantongi sertifikat Halal dari Majelis Ulama Indonesia (MUI) hal inilah yang menjadikan salah satu pengaruh penting yang dapat menimbulkan komitmen wanita Indonesia khususnya di Kota Palu untuk terus membeli Lipstik Merek Wardah. Selain itu Wardah berkomitmen untuk terus menggunakan bahan-bahan alami untuk setiap kosmetik yang diproduksinya. 
Berdasarkan permasalahan ynag diuraikan dalam penelitian ini, maka tujuan yang ingin dicapai adalah untuk mengetahui citra merek dan komitmen secara simultan dan parsial berpengaruh signifikan terhadap pembelian kembali lipstik merek Wardah di Kota Palu.

\section{KAJIAN LITERATURE}

\section{Kesadaran Merek (Brand awareness)}

Durianto et al. (2004:124) mendefinisikan kesadaran merek adalah elemen ekuitas yang sangat penting bagi peusahaan karena kesadaran merek dapat berpengaruh secara langsung terhadap ekuitas merek. Kesadaran konsumen terhadap merek dapat digunakan oleh perusahaan sebagai sarana untuk memberikan pemahaman yang lebih mendalam mengenai suatu merek kepada konsumen. Durianto et al. (2004:131) mengungkapkan bahwa tingkat kesadaran merek sebagai tingkat kesadaran konsumen terhadap suatu merek dapat ditingkatkan melalui berbagai upaya berikut:

1. Suatu merek harus dapat menyampaikan pesan yang mudah diingat konsumen.

2. Pesan yang disampaikan harus berbeda dibandingkan merek lainnya. Selain itu, pesan yang disampaikan harus memiliki hubungan dengan merek dan kategori produknya.

3. Perusahaan disarankan memakai jingle lagu dan slogan yang menarik agar merek lebih mudah diingat oleh konsumen.

4. Symbol yang digunakan perusahaan sebaiknya memiliki hubungan dengan mereknya.

5. Perusahaan dapat menggunakan merek untuk melakukan perluasan poduk, sehingga merek tersebut akan semakin diingat oleh konsumen.

6. Perusahaan dapat memperkuat kesadaran merek melalui suatu isyarat yang sesuai dengan kategori produk, merek, atau keduanya.

7. Membentuk ingatan dalam pikiran konsumen akan lebih sulit dibandingkan dengan memperkenalkan suatu produk baru, sehingga perusahaan harus selalu melakukan pengulangan untuk meningkatkan ingatan konsumen terhadap merek.

\section{Asosiasi Merek (Brand assocition)}

Menurut Kotler dan Keller (2009) asosiasi merek adalah segala kesan yang muncul dibenak seseorang yang terkait dengan ingatannya mengenai suatu merek. Kesan-kesan yang timbul dibenak konsumen akibat berbagai macam hal seperti komunikasi pemasaran suatu merek, pengalaman orang lain maupun diri sendiri dalam mengkonsumsi merek tersebut. Asosiasi dan kesan yang terkait dengan merek tersebut akan semakin meningkat dengan semakin banyaknya pengalaman pelanggan dalam mengkonsumsi suatu merek atau dengan semakin seringnya penampakan merek tersebut dalam strategi komunikasinya. Menurut Widjaja (2007:121) Asosiasi Merek merupakan hal-hal lain yang penting dalam asosiasi merek adalah asosiasi yang menunjukkan fakta bahwa produk dapat digunakan untuk mengekspresikan gaya hidup, kelas social, dan peran professional atau yang dapat mengekspresikan asosiasi-asosiasi yang memerlukan aplikasi produk dan tipe-tipe orang yang menggunakan produk tersebut, toko yang menjual produk atau wiraniaganya.

Menurut (Aaker, 1997:214) terdapat tiga dimensi untuk mengukur Asosiasi Merek yaitu :

1) Atribut, yaitu Asosiasi yang dikaitkan dengan atribut produk, baik yang berhungan langsung maupun tidak langsung dengan produknya.

2) Manfaat, yaitu Asosiasi Merek yang dikaitkan dengan manfaat secara fungsional, manfaat secara simbolis, dan pengalaman yang dirasakan oleh pelanggan.

3) Attitude, yaitu evaluasi kesukaan atas penggunaan produk, Asosiasi ini berkaitan dengan motivasi diri sendiri yang merupakan bentuk perilaku yang bersumber dari bentuk-bentuk penghargaan, penerimaan, dan pengetahuan terhadap produk. Asosiasi ini terbentuk dari gabungan asosiasi atribut serta manfaat yang diciptakan. 


\section{Citra Merek (Brand Image)}

Citra merek adalah persepsi dan kepercayaan oleh konsumen sebagai gambaran dari asosiasi yang terdapat dalam memori konsumen. Pengertian citra menurut Kotler dan Keller (2012:274) adalah cara masyarakat menganggap merek secara aktual. Agar citra dapat tertanam dalam pikiran konsumen, pemasar harus memperlihatkan identitas merek melalui saran komunikasi dan kontak merek yang tersedia. Citra terhadap merek berhubungan dengan sikap yang berupa keyakinan dan preferensi terhadap suatu merek (Sangadji dan Sopiah, 2013). Rangkuti (2004) mengemukakan bahwa citra merek adalah sekumpulan asosiasi merek yang terbentuk di benak konsumen. Menurut Aaker dalam Sangadji dan Sopiah (2013) citra merek seperangkat asosiasi unik yang ingin diciptakan atau di pelihara oleh pemasar. Asosiasi-asosiasi itu menyatakan apa sesungguhnya merek dan apa yang dijanjikan kepada konsumen.

\section{Komitmen}

Morgan dan Hunt (1994) mendefinisikan komitmen sebagai hubungan yang berjalan dengan yang lainnya dan membutuhkan usaha untuk memeliharanya. Komitmen yang tercipta antara perusahaan dengan pelanggannya akan menciptakan kondisi tertentu yang kemudian akan mendorong tindakan untuk memastikan kelanjutan hubungan. Jelas dapat terlihat bahwa komitmen tersebut berorientasi jangka panjang.

Morgan dan Hunt (1994) berpendapat bahwa komitmen terdiri dari dua komponen yakni:

1. Kepercayaan

Kepercayaan adalah suatu keadaan yang terjadi ketika seorang mitra percaya atas keandalan serta kejujuran mitranya. Kepercayaan melibatkan kesediaan seseorang untuk bertingkah laku tertentu karena keyakinan bahwa mitranya akan memberikan apa yang ia harapkan dan suatu harapan yang umumnya dimiliki seseorang bahwa kata, janji atau pernyataan orang lain dapat dipercaya.

2. Kepuasan

Kepuasan adalah tingkat perasaan konsumen setelah membandingkan antara apa yang dia terima dan harapannya (Umar, 2005:65). Seorang pelanggan, jika merasa puas dengan nilai yang diberikan oleh produk atau jasa, sangat besar kemungkinannya menjadi pelanggan dalam waktu yang lama.

\section{Perilaku Konsumen}

Engel et al. (2006) dalam Sangadji (2013:8) mendefinisikan perilaku konsumen sebagai tindakan yang langsung terlibat dalam pemerolehan, pengonsumsian, dan penghabisan produk dan jasa, termasuk proses keputusan yang mendahului dan menyusuli tindakan ini. Subjek ini dapat diancangi dari beberapa perspektif yang semuanya dipertimbangkan, yaitu: 1) pengaruh konsumen (consumer influence); 2) menyeluruh (wholistic); dan 3) antarbudaya (intercultural).

Kotler (2005) dalam Sangadji (2013:8) menjelaskan perilaku konsumen sebagai suatu studi tentang unit pembelian bisa perorangan, kelompok, atau organisasi. Masing-masing unit tersebut akan membentuk pasar sehingga muncul pasar individu atau pasar konsumen, unit pembelian kelompok, dan pasar bisnis yang dibentuk organisasi.

McKechnie (2012) dalam Sangadji (2013:9) mendefenisikan The field of Consumen Behavior: "Studies how individuals, groups, and organizations select, buy, use, and dispose of goods, services, ideas, or experiences to satisfy their needs and desires."

Berdasarkan tiga pengertian di atas, dapat disimpulkan bahwa perilaku konsumen adalah tindakantindakan yang dilakukan oleh individu, kelompok, atau organisasi yang berhubungan dengan proses pengambilan keputusan dalam mendapatkan, menggunakan barang-barang atau jasa ekonomis yang dapat dipengaruhi lingkungan. 


\section{Pembelian Kembali}

Minat membeli kembali terjadi setelah konsumen melakukan pembelian, dapat dikarenakan pernah mengkonsumsi sehingga berminat lagi untuk membeli kembali produk atau jasa yang sama. Oleh Karena itu, dapat disimpulkan bahwa repurchase intention merupakan hasrat atau keinginan yang timbul dalam diri konsumen untuk membeli produk atau jasa yang disukainya dan sebelumnya pernah membelinya berdasarkan hasil evaluasi atas kesesuaian kinerja produk atau jasa dengan harapan konsumen.

Terdapat beberapa faktor yang dapat mempengaruhi konsumen dalam minat pembelian, baik faktor internal maupun eksternal. Faktor internal dari dalam diri konsumen yakni kepercayaan dan sikap konsumen terhadap produk atau jasa, sedangkan factor pengganggu dari eksternal adalah sikap orang lain serta situasi tempat pembelian (Kotler, 2008:242). Konsumen akan lebih berminat membeli kembali suatu produk atau jasa apabila nilai yang ditawarkan suatu produk atau jasa mempunyai nilai yang sangat baik. Nilai tersebut benar-benar memberikan kesan positif dan menarik. Konsumen seringkali berniat melakukan pembelian karena di dasari oleh keinginan yang disertai emosi sehingga menjadikan niat pembelian semakin tinggi.

\section{Kerangka Pemikiran}

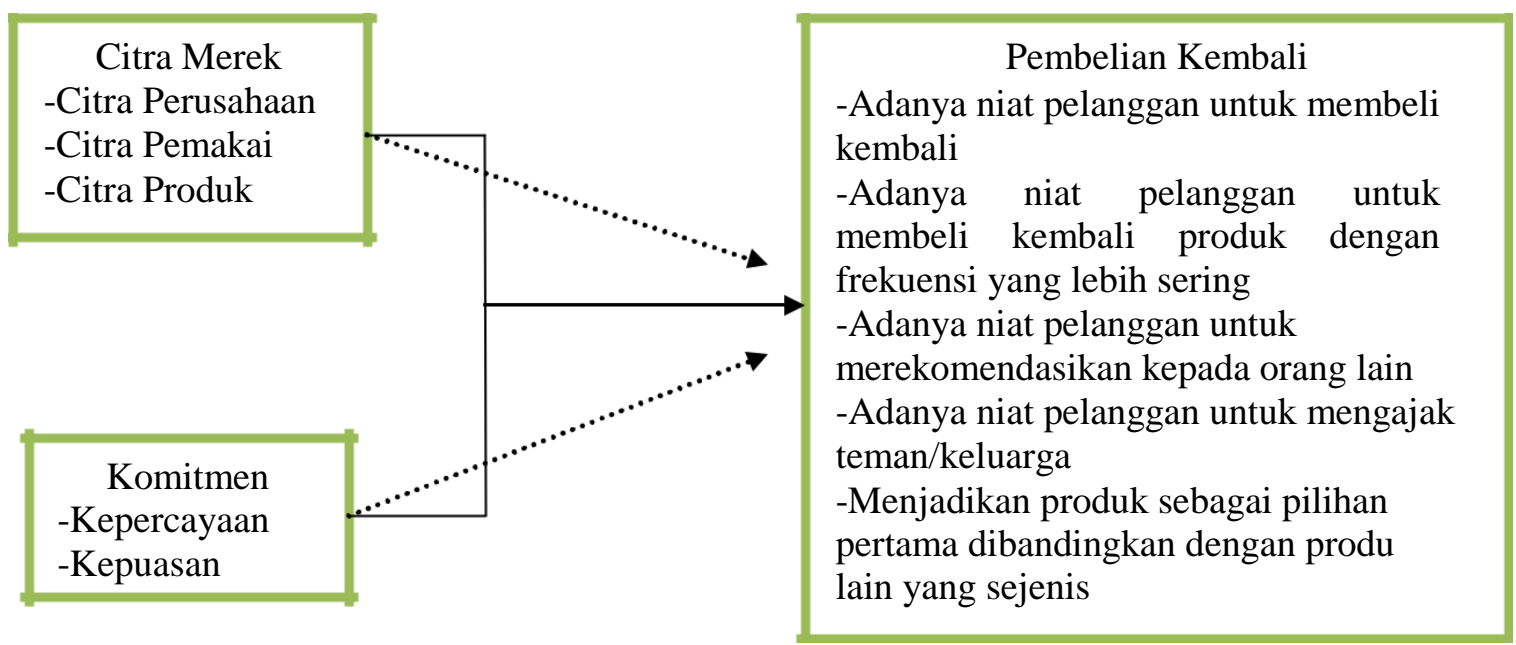

Keterangan:

$\mathbf{-}-\mathbf{D} \rightarrow$ Berpengaruh secara parsial

$\longrightarrow$ Berpengaruh secara simultan

\section{Gambar 1 Kerangka pemikiran}

Berdasaran teori dan kerangka berpikir di atas dapat disusun beberapa hipotesis sebagai berikut:

1. Citra merek dan komitmen secara simultan berpengaruh signifikan terhadap pembelian kembali lipstik merek Wardah di Kota Palu

2. Citra merek secara parsial berpengaruh signifikan terhadap pembelian kembali lipstik merek Wardah di Kota Palu

3. Komitmen secara parsial berpengaruh signifikan terhadap pembelian kembali lipstik merek Wardah di Kota Palu.

\section{METODE PENELITIAN}

Penelitian ini termasuk ke dalam jenis kausalitas karena penelitian ini bersifat menunjukan hubungan antar dua variabel atau lebih, atau bagaimana satu variabel mempengaruhi variabel lainnya (Umar, 2003:87). Peneliti melakukan survei untuk mengambil data di lapangan. Teknik pengumpulan 
data dengan pengamatan (wawancara atau kuesioner) yang tidak mendalam, dan hasil penelitian cenderung untuk digeneralisasikan.

Variabel-variabel dalam penelitian ini adalah:

1. Variabel bebas (Independent Variable)

Variabel bebas (X) dalam penelitian ini adalah Citra merek (X1) dan Komitmen (X2). Dimana perusahaan harus mengutamakan citra merek yang baik di benak pelanggan sehingga dapat menciptakan komitmen pelanggan untuk terus membeli kembali produknya. Beberapa indikator dari Brand Image yaitu Citra Perusahaan, Citra Pemakai, dan Citra Produk (Sutisna, 2001:80). Adapun beberapa indikator dari Komitmen yaitu, Kepercayaan dan Kepuasan (Morgan dan Hunt 1994).

2. Variabel Terikat (Dependent Variable)

Variabel terikat (Y) pada penelitian ini adalah Pembelian Kembali Lipstik merek Wardah di Kota Palu, yang terdiri dari beberapa indikator, yaitu: Adanya niat pelanggan untuk membeli kembali, adanya niat pelanggan untuk membeli kembali produk dengan frekuensi yang lebih sering, adanya niat pelanggan untuk merekomendasikan kepada orang lain, adanya niat pelanggan untuk mengajak teman/keluarga, menjadikan produk sebagai pilihan pertama dibandingkan dengan produk lain yang sejenis indikator yang digunakan dalam penelitian ini merupakan hasil elaborasi dari penelitian terdahulu.

Populasi dalam penelitian ini yaitu para konsumen yang telah menggunakan produk Lipstik merek Wardah di Kota Palu. Jumlah populasi dalam penelitian tidak diketahui secara pasti, dikarenakan tidak adanya data pendukung yang menunjukan data secara pasti konsumen yang telah menggunakan produk Lipstik merek Wardah.

Teknik pengambilan sampel untuk menentukan sampel yang akan digunakan dalam penelitian ini menggunakan teknik non probability sampling, yaitu purposive sampling. Purposive sampling adalah cara pengambilan sampel berdasarkan karakteristik tertentu.

Dikarenakan jumlah populasinya tidak diketahui secara pasti maka untuk menentukan besarnya sampel yaitu dengan menggunakan rumus Unknown Populations (Ekasari 2014: 98).

$\mathrm{n}=$

$$
\overline{4 \mu^{2}}
$$$$
\mathrm{Z}^{2}
$$

Keterangan:

$\mathrm{n}=$ ukuran sampel

$\mathrm{Z}=$ tingkat keyakinan sampel yang dibutuhkan dalam penelitian, pada $\alpha=5 \%$

(derajat keyakinan ditentukan 95\%) maka $\mathrm{Z}=1,96$

$\mu=$ margin of error, tingkat kesalahan yang dapat ditolerir (ditentukan 10\%)

Dengan menggunakan rumus diatas, maka diperoleh perhitungan sebagai berikut:

$$
\mathrm{n}=\frac{1,96^{2}}{4(0,1)^{2}}
$$

$\mathrm{n}=96,4 \approx 100$ responden

Penelitian ini menggunakan aplikasi software SPSS (Statistical Program for Social Scane) versi 16.0 yang dipakai untuk menganalisis pengaruh secara simultan dan pengaruh secara parsial variabel citra merek dan komitmen terhadap pembelian kembali. Adapun teknik analisis data yang dipergunakan dalam penelitian ini, yaitu analisis deskriptif dan analisis regresi linier berganda. 


\section{HASIL DAN PEMBAHASAN}

\section{Analisis Deskriptif}

1. Pengguna Lipstik wardah

Karakteristik responden berdasarkan Pengguna Lipstik wardah, Dari seluruh kuesioner yang diisi oleh 100 responden, seluruhnya adalah pengguna Lipstik merek wardah. Hal ini untuk memenuhi syarat pengambilan sampel berdasarkan karakteristik tertentu. Dan juga agar penelitian ini bersifat valid dan reliabel serta untuk menghindari terjadinya bias.

2. Usia

Berdasarkan hasil penelitian menunjukan bahwa dari total 100 responden dalam penelitian ini, merupakan responden yang berusia antara 17-25 tahun. Hal ini karena pada range usia tersebut, merupakan usia yang sering membeli peralatan kosmetik seperti Lipstik.

3. Pekerjaan Saat Ini

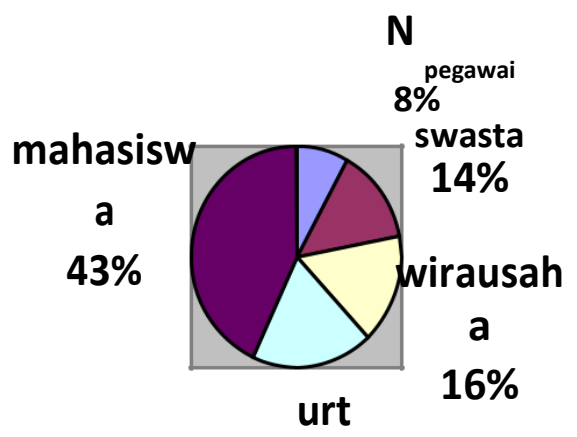

$19 \%$

Gambar 2 Karakteristik Responden Berdasarkan Pekerjaan

\section{Analisis Regresi Berganda}

Tabel 1 Ringkasan Hasil Uji Regresi Berganda

\begin{tabular}{|c|c|c|c|c|c|}
\hline \multicolumn{6}{|c|}{ Dependen Variabel Y = Pembelian Kembali } \\
\hline \multirow[t]{2}{*}{$\begin{array}{c}\text { Variabel Independen } \\
\text { (Dimensi Pesan Iklan) }\end{array}$} & \multicolumn{2}{|c|}{$\begin{array}{c}\text { Unstandardized } \\
\text { Coefficients }\end{array}$} & \multirow{2}{*}{$\begin{array}{c}\text { Standardized } \\
\text { Coefficients } \\
\text { Beta }\end{array}$} & \multirow[t]{2}{*}{$\mathbf{T}$} & \multirow[t]{2}{*}{ Sig } \\
\hline & B & $\begin{array}{l}\text { Standar } \\
\text { Error }\end{array}$ & & & \\
\hline $\mathrm{C}=$ Constanta & 2.149 & .322 & & 6.676 & .000 \\
\hline Citra merek $\left(\mathrm{X}_{1}\right)$ & .144 & .068 & .198 & 2.113 & .037 \\
\hline komitmen $\left(\mathrm{X}_{2}\right)$ & .330 & .072 & .430 & 4.597 & .000 \\
\hline $\begin{array}{lll}\text { Multiple R } & =.542 \\
\mathrm{R} \text { Square }\left(\mathrm{R}^{2}\right) & =.294 \\
\mathrm{E} & =.385\end{array}$ & & ig. $F=.000$ & & & \\
\hline
\end{tabular}

Berdasarkan hasil dalam table 1, maka persamaan regresinya adalah sebagai berikut:

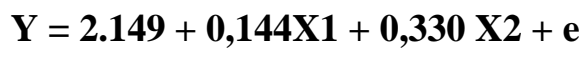

\section{Pembahasan}

\section{Pengujian Hipotesis Pertama (Uji F)}

Berdasarkan Tabel diatas, diperoleh angka signifikansi $F$ sebesar 0,000. Angka 0,000 $<0,05$ oleh karena itu, Ho ditolak dan Ha diterima. Artinya adanya pengaruh signifikan variabel citra merek $\left(\mathrm{X}_{1}\right)$ dan komitmen $\left(\mathrm{X}_{2}\right)$ terhadap pembelian kembali (Variabel $\mathrm{Y}$ ). 


\section{Pengujian Hipotesis Ke Dua dan ke Tiga (Hasil Uji t)}

\section{Variabel Citra merek $\left(\mathrm{X}_{1}\right)$}

Berdasarkan Tabel, hasil pengujian dengan SPSS diperoleh angka signifikansi sebesar 0,037. Angka $0,037<0,05$ oleh karena itu, hipotesis diterima. Hal ini berarti variabel $\mathrm{X}_{1}$ (citra merek) berpengaruh terhadap variabel Y (pembelian kembali).

2. Variabel Komitmen $\left(\mathrm{X}_{2}\right)$

Berdasarkan Tabel, hasil pengujian dengan SPSS angka signifikansi sebesar 0,000. Angka 0,000 < 0,05 oleh karena itu, hipotesis diterima. Hal ini berarti variabel $\mathrm{X}_{2}$ (komitmen) berpengaruh terhadap variabel Y (Pembelian kembali).

\section{Koefisien Determinasi $\left(\mathbf{R}^{2}\right)$}

Tabel 2 Koefisien Determinasi Model Summary

\begin{tabular}{|l|r|r|r|r|}
\hline Model & $\mathrm{R}$ & $\mathrm{R}$ Square & \multicolumn{1}{|c|}{$\begin{array}{c}\text { Adjusted R } \\
\text { Square }\end{array}$} & $\begin{array}{l}\text { Std. Error of the } \\
\text { Estimate }\end{array}$ \\
\hline 1 & $.542^{\mathrm{a}}$ & .294 & .279 & .38587 \\
\hline
\end{tabular}

Hasil perhitungan dengan menggunakan program SPSS versi 16 dapat diketahui bahwa koefisien determinasi yang diperoleh sebesar 0,294. Hal ini berarti 29,4\% pembelian kembali dapat dijelaskan oleh variabel citra merek dan komitmen, sedangkan sisanya yaitu 70,6\% pembelian kembali dipengaruhi oleh variabel-variabel lainnya yang tidak diteliti dalam penelitian ini.

\section{KESIMPULAN DAN SARAN}

\section{Kesimpulan}

1. Citra merek dan komitmen secara simultan berpengaruh signifikan terhadap pembelian kembali lipstik merek Wardah di Kota Palu. Hal tersebut menunjukan bahawa citra merek yang baik akan membuat konsumen berkomitmen untuk selalu menggunakan produk lipstik merek wardah.

2. Citra merek secara parsial berpengaruh signifikan terhadap pembelian kembali lipstik merek Wardah di Kota Palu. Hal tersebut berarti citra merek produk lipstik merek wardah yang terdiri dari citra perusahaan, citra pemakai dan citra produk telah memberikan kepuasan kepada konsumen sehingga konsumen melakukan pembelian kembali terhadap produk tersebut.

3. Komitmen secara parsial berpengaruh signifikan terhadap pembelian kembali lipstik merek Wardah di Kota Palu. Hal ini berarti komitmen yang terdiri dari kepercayaan dan kepuasan mampu membuat konsumen untuk terus melakukan pembelian kembali Lipstik merek wardah.

\section{Saran}

1. Bagi Perusahaan

1. Perusahaan wardah sebaiknya selalu menjaga citra merek agar kepercayaan pelanggan dapat terjaga kepada perusahaan untuk dapat tetap menjadi perusahaan kosmetik terbaik yang dapat membuat pelanggan puas dan berkomitmen. Menjaga citra merek dapat di mulai dengan memberikan nilai-nial positif bagi pelanggan.

2. Perusahaan Wardah dapat menambah pengalaman positifnya sehingga citra produk meningkat, dengan citra produk yang baik dan positif konsumen akan terus melakukan pembelian kembali bahkan akan merekomendasikan ke konsumen lainnya. Hal ini berarti, pelanggan berkomitmen untuk selalu menggunakan produk yang bercitra baik dan positif. 
c) Disarankan perusahaan untuk selalu berinovasi dalam menciptakan produk kosmetik khususnya produk lipstik. Dengan inovasi seperti pilihan warna dan kandungan yang aman akan membuat konsumen yang sebelumnya tidak membeli menjadi membeli dan konsumen yang sudah membeli menjadi ingin terus membeli kembali bahkan berkomitmen untuk selalu menggunakan produk yang memberikan kepuasan.

\section{Bagi Peneliti Selanjutnya}

Bagi peneliti selanjutnya yang ingin meneliti atau melanjutkan penelitian ini, disarankan untuk meneruskan atau mengembangkan penelitian ini dengan mencari faktor lain yang dapat mempengaruhi pembelian kembali lipstik merek wardah di Kota Palu. Selain menggunakan media online untuk menyebarkan kuesioner, penelitian selanjutnya sebaiknya disertai dengan wawancara sehingga data yang diperoleh lebih lengkap dan dapat mengurangi data yang bersifat subyektif.

\section{REFERENSI}

Aaker, David. (1997). Manajemen Ekuitas Merek. Jakarta: Spektrum.

Durianto, D., Sugiharto dan L.J. Budiman. (2004). Brand Equity Ten-Strategi memimpin pasar. Jakarta: PT. Gramedia Pustaka Utama.

Ekasari, Novita. (2014). Pengaruh Promosi Berbasis Social Media Terhadap Keputusan Pembelian Produk Jasa Pembiayaan Kendaraan PT. BFI Finance Jambi. Jurnal Penelitian Seri Humaniora Volume 16, Nomor 2, Hal. 81-102 ISSN: 0852-8349.

Kotler, Philip Dan Kevin, Lane Keller. (2008). Manajemen Pemasaran Jilid 1. Edisi Ketiga Belas, Terjemahan Bob Sabran, Mm. Jakarta: Penerbit Erlangga.

Kotler, Philip, dan Kevin Lane Keller. (2009). Manajemen Pemasaran, Jilid 2 Edisi Ketiga Belas. Jakarta: Penerbit Erlangga.

Kotler, P.\& Keller, K.L. (2012). Marketing Management (13th ed.). New Jersey: Prentice Hall, Inc.

Morgan, Robert Dan Shelby D. Hunt. (1994). "The Commitment - Trust Theory O Relationship Marketing, Journal Of Marketing, 58 (July), 20-38.

Rangkuti, Freddy. (2004). The Power of Brand, Teknik Mengelola Brand Equity dan Strategi Pengembangan Merek. Jakarta: PT. Gramedia Pustaka Utama.

Sangadji, Etta Mamang Dan Sopiah. (2013). Perilaku Konsumen. Yogyakarta: CV.Andi Offset. Sutisna. (2001). Perilaku Konsumen dan Komunikasi Pemasaran. Bandung: PT. Remaja.

Umar,Husein. (2003). Metodologi Penelitian: Aplikasi Dalam Pemasaran. Jakarta: PT. Gramedia Pustaka Utama.

Husein Umar, (2005). Riset Pemasaran dan Perilaku Konsumen, Jakarta: PT. Gramedia Pustaka Utama.

Widjaja, A. (2007). Audit Manajemen. Jakarta: Rineka Cipta. www.Marketers.Com. (Di Akses 16 Januari 2017) 